\title{
Legislation, Delegation and Implementation under the Treaty of Lisbon: Typology Meets Reality
}

\author{
Herwig Hofmann*
}

\begin{abstract}
The Treaty of Lisbon has introduced a complex new typology of acts, distinguishing between legislative, delegated and implementing acts. This reform, the first since the Treaty of Rome, will have an impact on some of the most contested topics of EU law, touching several central questions of a constitutional nature. This article critically analyses which potential effects and consequences the reform will have. It looks, inter alia, at the aspects of the shifting relation between EU institutions, the distribution of powers between the EU and its Member States, as well as the future of rule-making and implementation structures such as comitology and agencies.
\end{abstract}

Amongst the questions which have plagued the EU/EC legal system since its very beginnings are how to distinguish legislation from implementation on the European level, as well as the conditions for delegation of powers. The Treaty of Lisbon ${ }^{1}$ is an important step in the ongoing reform of the constitutional basis of the EU, addressing, inter alia, these very issues. This article therefore looks at the consequences of this new typology to the legal system of the EU and the effects of the distinction between legislative, delegated and implementing acts on the balance of powers between institutions, between the EU and Member States, and on the future of comitology and agencies. The article begins with an overview of the background to the problematique of delegation, hierarchies of norms and typology of acts within the context of the development of the EU and the EC's legal system. It continues with an analysis of the nature and use of different levels of acts proposed by the Treaty of Lisbon. It then discusses delegation of executive powers in the EU under the Treaty of Lisbon. Thereby, it takes account of the gaps between the new Treaty provisions, on one hand, and problems developed through decades of evolutionary developments of the legal system, on the other. $^{2}$

* Professor of European and Transnational Public Law at the University of Luxembourg and Director of its Centre for European Law.

${ }^{1}$ Treaty of Lisbon amending the Treaty on European Union and the Treaty establishing the European Community, signed at Lisbon, 13 December 2007, [2007] OJ C306/1, cited in this article on the basis of the consolidated versions published in [2008] OJ C115/1 and [2008] OJ C115/47.

${ }^{2}$ Such 'gaps' between the formal constitution and the institutional reality arise, eg, from the development of the use of forms of 'atypical legal acts', comitology, agencies and administrative networks. They can be problematic with respect to the legal framework governing executive action on the Union level. See, eg, 


\section{Delegation, Hierarchy and the Typology of Acts}

The typology of acts under the Treaty of Lisbon has had a complex historical genesis. It was born from the necessity to create a more self-effacing project than the Treaty establishing a Constitution for Europe (Constitutional Treaty, CT) ${ }^{3}$ had been. Both have in common that they are reform treaties addressing institutional needs of the EU. In both, one of the most important items on the agenda of reform was the simplification of the legal system by creating a new typology of legal acts of the EU. Such a reform has implications for many aspects of the legal and political system of the EU, most notably the further development of the 'institutional balance' at the European level. This is the European code for 'separation of powers' and its inherent 'system of checks and balances'. ${ }^{4}$ A reform of the typology of acts also has implications for legitimacy of governing through influencing transparency and intelligibility of legal acts and decision-making mechanisms. It finally influences the distribution of powers between the Member States and the EU.

The problem of the typology of acts addressed in the Treaty of Lisbon is not new. ${ }^{5}$ For nearly as long as the EC has existed, has there been debate about the necessity of a re-classification of the typology of $\mathrm{E}(\mathrm{E}) \mathrm{C}$ and $\mathrm{EU}$ legal acts and delegation of powers. ${ }^{6}$ The parameters of the debate changed over time with generations of treaty reforms, from the Single European Act to the Treaties of Maastricht, Amsterdam and Nice, ${ }^{7}$ and later the proposals for a treaty establishing a constitution for Europe (Constitutional Treaty). ${ }^{8}$ Alongside these 'constitutional' developments were no less

G. de Búrca, 'The Institutional Development of the EU', in P. Craig and G. de Búrca (eds), The Evolution of EU Law (Oxford University Press, 1999), 61; D. Curtin, 'Delegation to Non-Majoritarian Agencies and Emerging Practices of Public Accountability', in D. Geradin, R. Munoz and N. Petit (eds), Regulation through Agencies in the EU (Elgar, 2005), 88.

3 [2004] OJ C310/1.

4 Final Report of Working Group IX on Simplification (CONV 424/02, 29 November 2002), at 2; for the general effect of the institutional balance, see, eg, K. Lenaerts and A. Verhoeven, 'Institutional Balance as a Guarantee for Democracy in EU Governance', in C. Joerges and R. Dehousse (eds), Good Governance in Europe's Integrated Market (Oxford University Press, 2002), at 35 et seq.

${ }^{5}$ See for a summary of the debates leading up to the Constitutional Treaty, P. Stancanelli, 'Le système décisionnel de l'Union', in G. Amato, H. Bribosa and B. de Witte (eds), Genèse et destinée de la Constitution européenne (Bruylandt, 2007), 485.

${ }^{6}$ The first pillar has a catalogue of legal acts laid down in Art 249 EC (regulations, directives, decisions as well as recommendations and opinions). This catalogue is not exhaustive. The EC Treaty provides for additional types of legal acts in individual treaty provisions. The second and third pillars each have their distinct typology of legal acts defined in the relevant articles of the EU Treaty (for the second pillar (Common Foreign and Security Policy) in Art 12 et seq; EU with 'principles and general guidelines', 'common strategies' and 'decisions' in Art 13(1)-(3) EU; 'joint actions' Art 14 EU and 'common positions' Art $15 \mathrm{EU}$; in the framework of the third pillar, Art 34(2)(a)-(d) provides for common positions, framework decisions, decisions and conventions).

${ }^{7}$ Such parameters were the strengthening of the European Parliament within the institutional triangle, the transfer of an increasing amount of matters into (qualified) majority voting procedures in Council and the development of the system of delegating implementing powers to the Commission. These changes were accompanied by a dramatic enlargement of the number of Member States and the increase in policy areas addressed through European integration.

${ }^{8}$ This typology is a further development of the 2004 draft Treaty establishing a constitution for Europe's (Constitutional Treaty) proposals. For further details on the Constitutional Treaty's typology of acts, see, eg, J. Bast, Grundbegriffe der Handlungsformen der EU (Springer, 2006); L. Burgorgue-Larsen, A. Levade and F. Picod (eds), Traité établissant une Constitution pour l'Europe Commentaire article par article, Tome 1 (Bruylant, 2007); C. Callies and M. Ruffert (eds), Verfassung der Europäischen Union Kommentar der Grundlagenbestimmungen (Beck Manz, 2006); V. Constantinesco, Y. Gautier and V. Michel, Le Traité 
important evolutionary developments of legal practice influencing the structure of the legal system, such as the development of comitology committees and agencies. ${ }^{9}$ These developments posed important questions, especially with respect to the extent and form of delegation of executive powers. Looking at delegation problems and the distribution between legislative and executive rule-making and decision-making powers under the Treaty of Lisbon in the historical context shows three main overarching and interrelated themes. These kept the discussion alive over several decades, but also complicated the search for solutions.

The first theme is the question of democratic legitimacy of EC/EU decision making, ${ }^{10}$ asking whether the original Community model, which had come to be known as the Monet-method, should be changed towards a parliamentary model of government for the EU. Originally, the exercise of public powers by the EU was the result of a limited transfer of regulatory power to the European level. There it was exercised by an institutional tandem consisting of the Commission and Council. The Commission, under this model, acted similar to an independent agency under the review of legality by the Member States in the Council. This model has come to be described as the regulatory model of an expertise-driven decision making. ${ }^{11}$ The 'emancipation' of the European Parliament (EP) in treaty amendments from the Single European Act to the Treaty of Nice led to an increasing parliamentarisation of the government system. The dispute between these different visions of the nature of government and governance structures in the EU has been an underlying theme in the reform debates ever since.

The second main theme in the debate was linked to the first. It was whether EC rule making could actually be understood as 'legislation' in the sense developed in Member State constitutions with a strong parliamentary role. ${ }^{12}$ Instead, under the regulatory model, rule making under the original Treaty of Rome had often been regarded as

établissant une Constitution pour l'Europe Analyses \& Commentaires (Presses Universitaires de Strasbourg, 2005); J.-L. Sauron, Comprendre le Traité de Lisbonne (Gualino Editeur, 2008).

9 For details, see H. C. H. Hofmann and A. Türk, 'Policy Implementation', in H. C. H. Hofmann and A. Türk (eds), EU Administrative Governance (Elgar, 2006), 76.

10 The connection between this theme and the initiatives to reform the typology of EC legal acts can be illustrated when looking at the European Parliament 1984 draft Treaty Establishing the European Union, [1984] OJ C77/33. The European Parliament therein intended to establish itself as a 'second chamber' co-legislating together with the Council and controlling and supervising delegation of executive powers to the Commission.

11 The regulatory model views the Community as a special purpose organisation referred to by one of its original proponents as 'Zweckverband'. According to this model, the sole purpose of the EU is to pool sovereignty and regulate issues with greater efficiency than the Member States governments would be able to manage individually. It is based on the idea of the EU as a Community with limited competences to regulate technical matters delegated by the Member States. See for an excellent summary of this model, K. Lenaerts and A. Verhoeven, 'Institutional Balance and Democracy', in Joerges and Dehousse, op cit $\mathrm{n}$ 4 supra, 35, at 55. A proponent of this approach is Majone; see, eg, G. Majone (ed), Regulating Europe (Routledge, 1996).

12 These discussions existed despite the fact that the ECJ, in one of its first cases, had declared that general decisions under the ECSC 'are quasi legislative measures adopted by a public authority with legislative effect erga omnes'. The ECJ used this terminology to describe the special kind of rule making by an authority of neither international public law character nor comparable to national systems. The Community's quasi-legislation has direct effect without the necessity of national ratification and is subject to judicial review only by the ECJ: Case 8/55, Fédération Charbonière de Belgique v High Authority of the European Coal and Steel Community [1954-1956] ECR 245, at 258. The ECJ was thereby more outspoken about the nature of Community rule making than the EEC Treaty had been. 
technical regulation, delegated to the EC by the Member States. According to this view, EC legislation was characterised by the use of expert knowledge, the rationality of which was strictly task-related, neutral to compromise and fairly independent of political interest representation. ${ }^{13}$ This problem has also been overcome in the past with an increase in EP powers within the decision-making process. It was hidden by the fact that no reform of the original $\mathrm{E}(\mathrm{E}) \mathrm{C}$ typology of acts had been undertaken and, thus, the term 'legislative' remained hidden away in Article 207(3) EC. ${ }^{14}$

Linked to the first two themes of debate and the underlying conflict of models of legitimate exercise of public power is a related third major theme in the debate: the issue of the appropriate 'institutional balance'. ${ }^{15}$ Depending on the position in the debate, different concepts were developed for the role of the EP in legislative matters and for its supervisory powers with respect to the Community. The background to the debate was the ongoing inter-institutional conflict on the conditions for delegation of executive competences to the Commission and the system of comitology committees. Here the EP tried to establish the right to become involved in supervision of delegated powers through gaining rights in order to foster the parliamentary vis-à-vis the regulatory model of legitimacy. ${ }^{16}$

In view of these past debates and developments, the original draft of the Treaty of Lisbon's new typology of acts was established by the Laeken convention's working group on 'simplification' when it prepared the Constitutional Treaty. ${ }^{17}$ That working group based its considerations on former constitutional designs for the EU and a comparative look at various national constitutions. After brief and internal discussion, it developed a rather complex model comprising three levels of acts. It provided for legislative acts (as laws and framework laws), delegated regulations and implementing acts. ${ }^{18}$ The subsequent deliberations for the Treaty of Lisbon were based on the Constitutional Treaty's concepts. They were kept deliberatively brief and

${ }^{13}$ H. P. Ipsen, Zur Exekutivrechtsetzung in der Europäischen Gemeinschaft', in P. Badura and R. Scholz (eds), Wege und Verfahren des Verfassungslebens (Beck, 1993), 425 with further references.

14 This article refers to the rules of procedure of the Council. Under Art 7 of the Council's rules of procedure ([2004] OJ L106/22), the Council acts in its legislative capacity within the meaning of the second subparagraph of Art 207(3) EC when it adopts rules which are legally binding in or for the Member States, by means of regulations, directives, framework decisions or decisions, on the basis of the relevant provisions of the treaties, with the exception of discussions leading to the adoption of internal measures, administrative or budgetary acts, acts concerning inter-institutional or international relations or non-binding acts (such as conclusions, recommendations or resolutions).

${ }^{15}$ For a review of the discussions on the Intergovernmental Conference leading to the Treaty of Maastricht, see J. Cloos et al, Le Traité de Maastricht: genèse, analyse, commentaires (Bruylant, 2nd edn, 1994), at 369-373; for a full list of literature references, see H. C. H. Hofmann, 'A Critical Analysis of the new Typology of Acts in the Draft Treaty Establishing a Constitution for Europe', (2003) 7 European Integration Online Papers (EIoP) 1, available at http://www.eiop.or.at; H. C. H. Hofmann, Normenhierarchien im Europäischen Gemeinschaftsrecht (Duncker und Humblot, 2000).

${ }^{16}$ See the comitology decisions of 1987, 1999 and 2006 (Council Decision of 17 July 2006 amending Decision 1999/468/EC laying down the procedures for the exercise of implementing powers conferred on the Commission, [2006] OJ L200/11; Council Decision of 28 June 1999 laying down the procedures for the exercise of implementing powers conferred on the Commission, [1999] OJ L184/23; Council Decision of 13 July 1987 laying down the procedures for the exercise of implementing powers conferred on the Commission, [1987] OJ L197/33.

${ }^{17}$ P. Stancanelli, 'Le système décisionnel de l'Union', in Amato et al, op cit n 5 supra, 485, at 501.

${ }^{18}$ Articles 32-36 of the Treaty establishing a Constitution for Europe and their commentaries in BurgorgueLarsen et al, op cit $\mathrm{n} 8$ supra; Callies and Ruffert, op cit $\mathrm{n} 8$ supra; Constantinesco et al, op cit $\mathrm{n} 8$ supra; Sauron, op cit n 8 supra. 
technical in order to avoid any substantive re-negotiation of the Constitutional Treaty. One of the explicit objectives was to shed any constitutional language from the draft text in order to avoid the public perception of the Treaty of Lisbon as being a 'Constitution' instead of merely a 'constitutional' document. ${ }^{19}$ In a brief exchange between the lawyers of the institutions, a new typology of acts was developed. It now consists of a hybrid of old EC Treaty type acts mixed with concepts from the Constitutional Treaty. Like the Constitutional Treaty, the Treaty of Lisbon establishes one single typology for what is now the first and the third pillar of the EU Treaty, but maintains a special typology for the Common Foreign and Security Policy (CFSP). Unlike the Constitutional Treaty, the forms of binding legal acts remain regulations, directives and decisions (Article 288 of the Treaty on the Functioning of the European Union (FEU)). The definition of a 'decision' in the Constitutional Treaty followed the model of the decision in Article 14 of the European Coal and Steel Community (ECSC) Treaty, which simply declared a decision to be binding in its entirety and does not necessarily need to indicate to whom it is addressed. In this vein, Article 288 FEU clarifies that decisions can either be binding in their entirety or be addressed to individual addressees. ${ }^{20}$

Regulations, directives and decisions under the new typology can be issued in three different levels of Union acts. ${ }^{21}$ The first level consists of legislative acts. These are defined in Article $289 \mathrm{FEU}$ as the outcome of the co-decision procedure which has now become 'the ordinary legislative procedure'. The second level contains delegated acts. Article 290 FEU defines these as 'non-legislative acts of general application to supplement or amend certain non-essential elements of the legislative act'. The third level consists of implementing acts, defined in Article 291 FEU as acts for cases 'where uniform conditions for implementing legally binding Union acts are needed'. Altogether there are thus nine basic categories of binding acts (regulations, directives and decisions issued as either legislative, delegated or implementing acts). Next to these, Article 296 FEU explicitly acknowledges the instrument of inter-institutional agreements and Article 216 FEU international agreements. Other specific forms of act exist, for example, for budget matters (Article $313 \mathrm{FEU}$ ).

Limitations for the use of different instruments arise from two sources. First, for all levels of acts (legislative, delegated and implementing), indications for the choice of act arise from the principle of conferral. A treaty provision may limit the legislative choice of the legal instrument by, for example, requesting the use of a directive or

19 'Constitutional charter' was the terminology the ECJ had used in earlier case-law to describe the EC Treaty's nature as the founding charter of the Community in Case 294/83, Les Verts [1986] ECR 1339, para 23.

${ }^{20}$ This allows for its application in CFSP matters. Also, this wider definition will do away with the differentiation between 'normal' and 'atypical' decisions. The latter differentiation had caused confusion in the past, because not all languages have the terminology to differentiate between these different legal terms for these different forms of acts. For example, French and English use 'decision' for both. In Dutch and German the distinction was drawn between the formal decision under Article 249 EC and the atypical 'Besluit' or 'Beschluß', which are decisions without a (potential) addressee. The decision under the definition of Art 289 FEU will allow replacing the current CFSP 'joint actions' and 'common positions'. Also, what was so far the Council's comitology 'decision' will in future be replaced with a formal legislative act decided under co-decision (Art 291(3) FEU).

${ }^{21}$ If one counts the level of treaty provisions (new Art 33 of the Treaty on European Union), the Treaty of Lisbon will contain four levels of acts, each with a different decision-making procedure provided for by the treaty. 
regulation..$^{22}$ Second, limits arise also from Article 296(3) FEU, which requests legislative acts to 'refrain' from adopting acts 'not provided for in the relevant legislative procedure in the area in question', ${ }^{23}$

In summary, pursuant to the system provided for in the Treaty of Lisbon, the EP and Council can act together in the legislative procedure to issue legislative acts (Article 289 FEU). The Commission can, when it has received specific delegation, issue either delegated acts (Article 290 FEU) or implementing acts (Article 291 FEU). The Council can in exceptional cases also be the recipient of delegation to issue implementing acts under Article 291 FEU. Special categories of act continue to exist for the CFSP. ${ }^{24}$

\section{The New Typology of Acts under the Treaty of Lisbon}

In a first analysis, before turning to the potential future legal problems and challenges of the new typology of acts, the following sub-sections will address the definition and particularities of the three new levels of legislative delegated and implementing acts.

\section{A Legislative Acts}

Legislative acts under the definition of the Lisbon Treaty have a formal definition. They are regulations, directives or decisions that have been adopted in the ordinary "legislative procedure', a slightly reformed co-decision procedure. ${ }^{25}$ This is a change to the situation under the EC treaty, under which procedural provisions for a decision were defined in each policy matter. The existence of many different legislative procedures, both in the first and third pillars of the EU, has been a source of constant interinstitutional conflict about the correct legal basis indicating different balance of

${ }^{22}$ eg in the area of services, such as Art 44(1) EC, which require the use of directives in order to obtain the freedom of establishment with respect to certain activities, as well as Arts 46(2), 47(1), 47(2) and 52(1) EC for other aspects thereof.

${ }^{23}$ One might argue though that Art 296(3) FEU contains a sort of hidden opening clause for atypical acts. This Article states that the EP and Council 'when considering draft legislative acts . . shall refrain from adopting acts not provided for by the relevant legislative procedure', Other languages than the English version clarify to a greater degree that this is meant to be a prohibition of atypical acts of formal legislation. The German text, eg, reads, 'so nehmen sie keine Akte an, die nach dem für den betreffenden Gesetzgebungsverfahren nicht vorgesehen sind'. The French version declares that the legislative bodies 's'abstiennent d'adopter des acts non-prévus par la procédure législative applicable au domaine concerné'. This provision indicates not only that the choices of the relevant Treaty provisions are to be adhered to - which states the obvious - but also that only with respect to legislative acts, the typology of acts that is provided for in the EU Treaty and the FEU final. On the level of implementing acts, types of acts other than those listed in Art 288 FEU (regulations, directives and decisions) may be adopted. Since this prohibition of adopting so-called atypical acts is explicitly limited to the level of legislative acts, in the absence of limits in the delegating act, delegated acts and implementing measures can be issued as atypical acts.

24 Article 25 EU (Lisbon) provides for (a) general guidelines; (b) decisions on (i) actions, (ii) positions and (iii) arrangements for implementation of the former; as well as (c) arrangements for cooperation between the Member States. Decisions are taken in the extraordinary decision-making procedure by the Council. Implementing measures under (b)(iii) can also be taken by the High Representative and the Member States (Art 26 EU (Lisbon)). The High Representative under Art 26(a) EU (Lisbon) shall ensure implementation of decisions on actions and positions in the area of the CFSP.

25 See Arts 288, 289 and 294 FEU. Of course there are also exceptions to this through special legislative procedures not defined in Art 294 FEU (ex. Art 251 EC), but in specific policy areas. Examples include budgetary provisions under Art 310 FEU. Other examples include the procedures to issue rules of procedure of institutions and statute of certain agencies. 
powers. ${ }^{26}$ Therefore, the FEU's uniform formal definition of a legislative act will be able to solve the majority of legal-basis conflicts in future.

However, despite the basically formal definition of legislative acts, there are also substantive definitions. They are derived not only from treaty provisions allocating competences to institutions other than those involved in the legislative procedure. They also derive from general legal principles protected by the EU legal system. ${ }^{27}$

The Treaty of Lisbon raises the question whether substantive limitations on addressing certain issues within EU competence in legislative acts also arise from the requirement only to issue acts of general application and not of individual application. An indicator arguing in favour of such a reading might be the formulation of Article 290 FEU. This states that delegated acts may be exclusively 'acts of general application'. If, as the argument might run, delegated sub-legislative acts may only be of general application, this would a contrario also be true of the 'higher' legislative acts. Such reading would result in the limitation of the maximum detail a legislative act could contain. This reading, however logical at first sight, seems not very convincing. In the structure of Articles 288-292 FEU, the definition of a legislative act is generally a formal one. Substantive limitations are an exception. This exception is not introduced as a distinction between implementing acts, on the one hand, and legislation and delegating acts, on the other. Rather, it should be read as an attempt to find differences between matters addressed by delegated acts and such matters addressed by implementing acts under Article 291 FEU. ${ }^{28}$ Individual acts will, under the new typology, generally be regarded as implementing acts subject to the specific procedures provided for in Article 291 FEU.

Substantive limitations also exist with respect to the delegation of legislative powers - in other words, rules on the minimum content of a legislative act. Pursuant to Article 290(1) FEU, a legislative act may delegate power to 'supplement or amend certain non-essential elements' of the delegating legislative act. Essential elements, on the other hand, are explicitly 'reserved for the legislative act and may not be subject to a delegation of power'. One of the weak points of this non-delegation clause introduced into the new typology of acts is that it is explicitly only formulated for delegated acts under Article 290 FEU. From a teleologic point of view, however, it should also be applicable for the distinction between legislative and implementing acts under Article 291 FEU.

The non-delegation clause in Article 290 FEU also raises questions as to the definition of essentialness. The provision gives an abstract answer by explaining that 'the objectives, content, scope and duration of the delegation of power' belong to the

\footnotetext{
${ }^{26}$ See for a background to the legal basis disputes within the first pillar, K. Bradley, 'The European Court and the Legal Basis of Community Legislation', (1988) 13 European Law Review 379. The leading case for the extensive case-law on this matter is Case C-300/89, (Titanium-Dioxide) Commission v Council [1991] ECR I-2867, paras 22-25; see K. Bradley, 'L'arret dioxyde de titiane un jugement de salomon?', (1992) 28 Cahiers de Droit Européen 609. As an example of the legal basis disputes between the first and the third pillar matters, see Case C-176/03, Commission v Council [2005] ECR I-7879, paras 39, 45 and 51.

27 Limits of the legislator's competencies are the prohibition of the legislator to address matters which are reserved for specific institutions. For example, such competencies have been allocated in primary law in the area of monetary policy to the ECB. Other treaty-based rules substantively limiting the legislator's competencies derive from the definition of the inter-institutional balance. An example of such a rule can be found in the distribution of powers defined in the field of external relations - the conclusion of agreements between the Community and other parties as provided for in Art 216 FEU.

28 I will return to the difficulties of distinguishing these two different categories of non-legislative acts below in this article.
} 
essential elements and shall be explicitly defined in the legislative act. Each legislative act will need to define these criteria on a case-by-case basis. The criteria are not only procedural in the sense that the legislator has to address these formally. The criteria are also substantive insofar as the objective, content and scope of a delegation needs to be actually defined in the legislative act. Whether the substantive nature of these criteria will guarantee effective limitations to the exercise of legislative discretion finally depends on their enforceability in court. The European Court of Justice's (ECJ) record in this respect is mixed. It has so far reviewed substantive criteria limiting legislative discretion mainly under procedural aspects. ${ }^{29}$ Also, the ECJ has so far been hesitant to review legislative discretion against an alternative interpretation of the substantive criteria. It has consistently limited its review of legislative discretion as to whether there has been 'manifest error or misuse of powers', or whether the institutions have 'manifestly exceeded the limits of discretion'.$^{30}$ If this were the criteria of review, it might be doubtful whether the substantive criteria limiting delegation in Article 290 FEU will be an effective constitutional barrier to delegation. An alternative, and probably more apt, approach would be to interpret the non-delegatable elements of 'objective, content, scope and duration of delegation' in a teleologic sense and require that an affected citizen should be able to know in advance the content and limits the delegated administrative regulation could legally have. ${ }^{31}$ This would comply with the idea to establish a minimum level of legislative detail and a guarantee against wholesale delegation away from parliamentary to a purely executive setting. The formulation of Article $290 \mathrm{FEU}$ indicates that both the extent of the delegation as well as the conditions are essential parts of the legislative act. Without an even implicit definition of these conditions, the delegating legislative act will suffer from an essential fault leading to the illegality of delegation..$^{32}$

Limitations to the legislator's discretion on delegation also arise from the ECJ's case-law on the distinction between legislative and implementing measures: the

${ }^{29}$ Case-law of the ECJ exists mainly with respect to the principle of subsidiarity under Art 5(2) EC. See especially Case C-84/94, Working Time Directive [1996] ECR I-5755; C-233/94, Deposit Guarantee Schemes [1997] ECR I-2405; C-377/98, Biotechnological Inventions [2001] ECR I-7079, paras 32 and 33; C-103/01, Protective Equipment for Firefighters [2003] ECR I-5369, para 47; more substantiated on the other hand, C-154/04, Alliance for Natural Health [2005] ECR I-6451, paras 101-106.

${ }^{30}$ See for many C-84/94, ibid, at 5811.

${ }^{31}$ This interpretation would be akin to the interpretation of the German Constitutional Court (Bundesverfassungsgericht) of the closely related formulation in Art 80(1) of the German Constitution (Grundgesetz) which requires a delegating act to define 'the content, the purpose and the extent' of the delegation (for case-law, see, eg, BVerfGE 80, 1, 21; BVerGE 68, 319, 333; BVerfGE 55, 207, 226). For earlier suggestions of referring to the German constitutional experience by introducing such wording into the definition of the EU typology of acts, see, eg, MEP Bourlanges, Eur Parl Deb Nr 3-404/135 (17 April 1991); MEP Rothley (Rapporteur), EP Committee on Institutional Affairs, Working Document on the categories of legal act of the European Union and the relationships between them (PE 211.103/ rev, 15 March 1995). Drawing direct comparisons with the constitutional experience of Member States must however always be approached with caution. Given the highly contextual nature of individual constitutional provisions and interpretations, the ECJ will need to find an EU-specific approach to the interpretation of the nondelegation clause in Art 290 FEU.

${ }^{32}$ An argument for this position arises from the comparison of the language versions of Article $290 \mathrm{FEU}$ showing that defining the conditions is not optional but an essential element of the delegating legislative act. The English version of the text states that 'legislative acts shall lay down the conditions'. The French and German versions, eg, seem to be slightly clearer in this respect by stating that 'les actes législatifs fixent explicitement les conditions' and 'die Bedingugnen unter denen die Übertragung erfolgt, werden in Gesetzgebungsakten ausdrücklich festgelegt'. 
former determining what should happen in principle; the latter determining how implementation of the principles will in fact take place. ${ }^{33}$ The latter are most often adopted under a comitology procedure. The ECJ developed criteria to review the Commission's action within the delegated powers. The most fundamental of these principles is that the Commission, when exercising delegated competences, first is bound by the terms of the delegation; second may not go beyond the scope of delegation; ${ }^{34}$ and third has to comply with the modalities defined in the act of delegation. ${ }^{35}$ These general principles also apply to the Council, if exceptionally implementing powers have been delegated to the Council instead of the Commission. ${ }^{36}$ Under the Treaty of Lisbon, these general criteria to review delegated powers, although having been developed under Articles 202 and 211 EC, will continue to exist. Unlike under the EC Treaty, the ECJ can now draw an explicit differentiation between general rules and rules for 'implementation'. ${ }^{37}$

In this context, however, it is necessary to recall that the ECJ has so far not developed abstract criteria for the differentiation between legislative matters. The ECJ's definition of the term 'implementation' differed according to the policy field to be judged. Most of the reported cases concerned agricultural policy. Therein, the ECJ held that it was sufficient for the Council to adopt the basic elements of a matter by the legislative procedure. ${ }^{38}$ The court held that 'it follows from the context of the Treaty' and 'from practical requirements' that the concept of implementation must be given a 'wide interpretation'. The Council thus confers extensive powers on the Commission. ${ }^{39}$ Therefore, basic or essential elements of a measure are provisions intended to shape the fundamental guidelines of Community policy..$^{40}$ In subject areas other than agricultural policy, the ECJ defined more narrow requirements for the precision of the delegating norm. ${ }^{41}$ In non-agriculture cases, the Court requested that the delegating provision

${ }^{33}$ See K. Bradley, 'Comitology and the Courts: Tales of the Unexpected', in Hofmann and Türk, op cit $\mathrm{n} 9$ supra, 417; Case 25/70, Einfuhr und Vorratsstelle v Köster [1970] ECR 1161, paras 9-10.

${ }^{34}$ Case $25 / 70$, ibid.

35 Case 6/71, Rheinmühlen v Einfuhr- und Vorratstelle für Getreide [1971] ECR 823, at 841; Case 34/78, Yoshida v Kamer van Koophandel en Fabrieken voor Friesland [1979] ECR 115; Case 114/78, Yoshida v Industrie- und Handelskammer Kassel [1979] ECR 151 and Opinion of Advocate General Capotorti of 13 December 1978, [1979] ECR 137, at140. The ECJ determines the limits of delegation on a case-by-case basis according to the policy area in question. See, eg, Case T-285/94, Pfloeschner v Commission [1995] ECR II-3029, at 3047, para 51; Case 38/70, Deutsche Tradax GmbH v Einfuhr-und Vorratstelle für Getreide und Futtermittel [1971] ECR 145, at 154.

${ }^{36}$ See, eg, C-303/94, Parliament v Council (Pesitcide) [1996] ECR I-2943.

37 Case 240/90, Germany v Commission [1992] ECR I-5383, at 5384, 5417-5419. None of the treaty provisions give a definition of the term of 'implementation'.

38 Case 25/70, op cit $\mathrm{n} 33$ supra, at 1170 , para 6.

39 Case 23/75, Rey Soda v Cassa Conguaglio Zucchero [1975] ECR 1279, at 1300, para 10 and 1301, para 14. See also Case 121/83, Zuckerfabrik Franken v Hauptzollamt Würzburg [1984] ECR 2039, at 2058; Joined Cases 133-136/85, RAUIBALM [1987] ECR 2289, at para 31; Case 46/86, Romkes v Officier van Justitie [1987] ECR 2685, at para 16; Case C-417/93, Parliament v Council [1995] ECR I-1185, at 1219, para 30; Case C-156/93, Parliament v Commission [1995] ECR I-2019, at 2047, para 18; Case C-303/94, Parliament $v$ Council [1996] ECR I-2943.

40 That is not true of penalties. 'In order to delegate to the Commission the power to provide for penalties in the sector of the common agricultural policy, a delegation of power couched in general terms is sufficient': Case C-240/90, Germany v Commission [1992] ECR I-5383, at 5384 and 5434 et seq.

41 'It must be pointed out that such a wide interpretation of the Commission's powers can be accepted only on the specific framework of the rules on agricultural markets ... It can not be relied upon to justify a provision adopted by the Commission on the basis of its implementing powers in agricultural matters where the purpose of the provision lies outside that sphere but within a sector subject to an exhaustive set 
itself must define the criteria for assessing the situation in question, as well as the kind of measures to be taken by the Commission and the period of their validity. ${ }^{42}$ In all cases, the implementing act must comply with provisions enacted in the delegating act; it may not be ultra vires. ${ }^{43}$ In the absence of any indications to the contrary, it seems that this developed case-law of the ECJ on delegation will continue to be applicable in the context of the new distinction between legislative acts under Articles 289 FEU and implementing acts in Article 291 FEU.

In summary, despite certain substantive elements to the definition of legislation, the definition of a legislative act basically follows a formal definition. ${ }^{44}$ This is convincing in its simplicity even if the terminology of legislative regulations, directives and decisions does not contribute to the transparency of the legal system.

\section{$B$ Delegated Acts}

With respect to the category of delegated acts in Article $290 \mathrm{FEU}$, four main questions arise. First, what is the nature of this type of act? Second, what are the conditions for delegation of legislative matters? Third, what are the possibilities to revoke a delegation or to object to the entry into force of a planned delegated act? ${ }^{45}$

Legislative acts may delegate to the Commission the power to adopt delegated acts under Article $290 \mathrm{FEU}$ issued as delegated regulations, delegated directives and delegated decisions (Article 288 FEU and Article 297 FEU). Other types of act are, however, also possible. This arises a contrario from Article 296(3) FEU, which explicitly excludes the use of atypical acts only for legislative and not for delegated acts. Atypical forms of acts such as plans and measures can also be issued as delegated acts. Delegated acts 'supplement or amend certain non-essential aspects' of a legislative matter. They thereby address legislative matters, albeit in a non-legislative decisionmaking procedure. Delegated acts are therefore substantive but not formal legislation. Under the wording of Article $290 \mathrm{FEU}$, delegated acts may not be issued as single-case measures, and may only be acts of general application. In reality however, this distinction is difficult to observe. Acts of general nature, supplementing or amending certain elements of legislative acts, can often have both an abstract-general and a concreteindividual application. ${ }^{46}$

of rules laid down by the Council': Case 22/88, Industrie- en Handelsonderneming Vreugdenhil BV $v$ Minister van Landbow en Visserij [1989] ECR 2049, at 2076.

42 eg Case 291/86, Central-Import Münster GmbH \& Co. KG v Hauptzollamt Münster [1988] ECR 3679, at 3706.

43 Case C 303/94, op cit $\mathrm{n} 33$ supra.

${ }^{44}$ Both delegated acts, as well as implementing acts, are therefore not formal legislation. They may, however, contain substantive legislation and may thus, eg, be regarded as 'law' in the sense of Art 52(1) of the Charter of Fundamental Rights of the European Union, requiring that any limitation on the exercise of fundamental rights and freedoms expressed in the charter must be based on law. For further explanation of the distinction between formal and substantive legislation in the EC context, see A. Türk, The Concept of Legislation in EC Law (Kluwer, 2006), at 77-120 and 187-236.

45 The question where the idea for such an instrument and the motivation to include it into the typology of EU legal acts arises from will be addressed in the following section together with considerations on consequence for the institutional balance.

${ }^{46}$ See, eg, annex lists fleshing out general provisions of legislation as was the case in T-306/01, Ahmed Ali Yusuf and Al Barakaat International Foundation v Council [2005] ECR II-3533 and Stancanelli, op cit n 5 supra, at 524 and 525. 
According to Article 290(1) FEU, the legislative act which delegates powers defines the 'objectives, content, scope and duration' of the delegation. Therefore, a delegated act will be subject, inter alia, to a limitation of its duration, ie containing a so called 'sunset clause'. Delegation there under will automatically be terminated with the expiration of the mandate. ${ }^{47}$ Such sunset clauses are essential if the EP and Council as legislator are not to lose all possibilities of reobtaining their once delegated powers. The risk is real given the Commission's near exclusive right of initiative and the fact that the Commission is also the sole benefactor of delegation. ${ }^{48}$

According to Article 290(2) FEU, the legislative act must also define the 'conditions to which the delegation is subject'. Two the possibilities are spelt out in Article 290 FEU: ${ }^{49}$ First, the Council or the EP may opt to revoke the entire delegation. ${ }^{50}$ The EP or the Council using its option will not need a Commission proposal for such a revocation decision. Second, the Council or the EP may object to a measure to be taken by the Commission as a delegated act. Under this procedure, one of the institutions will have the power to voice an objection. Only in the absence of an objection will the delegated act enter into force. The two different models therefore differ as to the extent of control and revocation powers. Only the first allows for a full-scale revocation of the power conferred on the Commission to issue delegated acts. The second allows only for a case-by-case review. Once the power to issue delegated acts has been granted to the Commission, under the second procedure there will be no possibility without a Commission proposal for an amendment of the act to regain the delegated powers other than the expiry of delegation through the sunset clause. ${ }^{51}$ Both control options of the EP and the Council are highly dependent on their timely and full information. Experience with this type of instrument will shape the legislator's willingness to delegate legislative powers to an essentially executive branch of powers. Political control of executive legislative powers is most effective if a delegating act contains both control

${ }^{47}$ In the earlier version of the draft Constitutional Treaty a third possibility was that the "provisions of the delegated regulation were to lapse after a period set by the law' (CONV 571/03, 26 February 2003), at 7.

${ }^{48}$ It is interesting to compare this approach with Art 38 of the French Constitution which allows for temporary delegation of legislative powers to the government. Article 38 of the French Constitution, however, gives exact conditions for such measures to remain in power after the end of the extraordinary time-limits. On the other hand, the powers which can be delegated are also more extensive than those under the power to delegate non-essential elements of legislation. Under French law, such powers may not be sub-delegated. See below for the possibility of sub-delegation under the construction of the typology of acts under Lisbon.

49 The list of possibilities in Art 290 FEU has been developed from conditions of delegation used in the British legal system's instruments to secure parliamentary review of delegated legislation. Legislation in the UK may be submitted to two basic procedures before being able to enter into force, known as the 'affirmative' and the 'negative' procedure. According to the (less used) affirmative procedure, no legislation may take effect until there has been approval of Parliament. According to the (more frequent) negative procedure, draft secondary legislation will take effect within a given period of time, unless there has been express disapproval by parliament: P. Leyland and T. Woods, Administrative Law (Oxford University Press, 4th edn, 2002), at 137.

${ }^{50}$ Generally, a revocation of an act is seen to have the same legal value as the creation of an act. However, in this case, arguably, given that the non-revocation is described in Art 290 as a condition, the nonrevocation could be regarded as condition for the validity of the act. So far, there is no need for an exception from Art 9d(2) EU, which stipulates that 'Union legislative acts may be adopted only on the basis of a Commission proposal except where the Treaties provide for otherwise' and no explicit exception from the requirement of a revocation exists.

51 This specificity of delegation problems arises from the Commission's exclusive right of initiative for legislative acts in Art 17(2) EU (Lisbon). 
options of Article $290 \mathrm{FEU}$, ie both the procedure to revoke the delegation altogether or to object only to a single measure.

A certain degree of ambivalence arises from the formulation of Article $290 \mathrm{FEU}$ and whether the list contained in this article is conclusive or contains only examples. ${ }^{52}$ However, there are reasons to argue that Article 290 FEU contains a closed enumeration. One of these arguments is the exceptional nature of the delegation of legislative powers to the executive body, the Commission. The delegation, being an exception, indicates the necessity of a narrow interpretation of the exception vis-à-vis the rule. The other argument for a closed enumeration is the required legitimacy of legislative acts. The arguments for an open interpretation are also strong. One of these is the need for flexible developments of new forms of conditions. If such interpretation were to prevail, the legislature would remain free to construct other review and recourse procedures. This possibility of choice would have the potential to spark inter-institutional conflict similar to the decades-old conflict on comitology.

\section{Implementing Acts}

The third category of standard acts under the Treaty of Lisbon is the category of implementing acts. Pursuant to Article 291 FEU 'where uniform conditions for implementation of legally binding acts are needed', those acts shall confer implementing powers on the Commission or exceptionally on the Council. Implementing acts will be issued in the form of implementing regulations, directives or decisions (Article 288 FEU) or as atypical acts (Article 273 FEU) ${ }^{53}$ Both legislative acts under Article 289 FEU, as well as delegated acts under Article 290 FEU, may confer implementing powers.

Like under the existing Article $202 \mathrm{EC},{ }^{54}$ under Article 291(3) FEU, delegation of implementing powers can be made subject to comitology procedures. This is hidden in the formulation that rules and general principles concerning mechanisms for control by Member States 'shall be laid down in advance in the ordinary legislative procedure'.

Implementing acts are presented in Article $291 \mathrm{FEU}$ as being purely unilateral regulations, directives and decisions. In reality, however, implementation takes place not only through acts which can unilaterally impose obligations on Member States and individual parties. Very often and to an increasing extent, implementation is undertaken by multilateral agreements between various kinds of actors - both public and private - at the European and the national levels. The contractual relations are the core of the emerging administrative network implementing EU policies. ${ }^{55}$ Since the EU as a whole will have legal personality under the new treaty arrangements, contracts under

${ }^{52}$ In most language versions, like in English, French, Spanish, Italian, Polish, Czech, Lithuanian, Slovak, Bulgarian, Danish and Dutch language versions, the wording of Art 290(2) FEU could be read as to contain a non-exhaustive list of examples. They read 'these conditions may be as follows', 'peuvent être les suivantes', 'que podrán ser las siguientes', 'che possono essere le seguenti', ' 'i moga być nastepujace', 'které mohou být tyto', 'kurios gali būti', 'ktoré mô.u byt takéto' and 'Тези условия могат да бъдат, както следва, 'og som kan være følgende', 'Dit kunnen de volgende voorwaarden zijn'. The German language version, on the other hand, could be interpreted to sound stricter and require only the limited choice: 'wobei folgende Möglichkeiten bestehen'.

${ }^{53}$ Article $273 \mathrm{FEU}$ requires EU institutions to refrain from atypical acts only when enacting legislative measures.

${ }^{54}$ Articles 202 and 211 EC will be replaced under the Treaty of Lisbon with the system of Arts 288-291 FEU.

${ }^{55}$ See H. C. H. Hofmann, 'Agreements in EU Law', (2006) 31 European Law Review 800. 
public and private law can be concluded by the EU and its institutions, as well as bodies such as agencies often having their own legal personality. However, despite their increasing importance in practice, the instrument of contracts and agreements should, however, have been much more prominently listed as an instrument of implementation next to implementing regulations and decisions. ${ }^{56}$ They continue to be only indirectly referred to under Articles 272 and 340 FEU.

\section{Acts for Common Foreign and Security Policy}

Although under the Treaty of Lisbon, like under the Constitutional Treaty, all three former pillars of the EU Treaty have been united, the typology of legal acts outlined in Articles 288-291 FEU does not contain an exhaustive list of acts. A specific typology of legal acts continues to exist for the area of the CFSP, including defence matters on the European level in Articles 12 and 13 EU (Lisbon). With this distinction between types of legal acts, the EU Treaty's pillar structure reappears within the Treaty of Lisbon. The former second pillar matters have a new, simplified typology of legal acts. The core of these new acts is the European decision. It is a sui-generis decision that is taken by the European Council or by Council of Ministers by unanimity. European decisions under CFSP are implemented by the High Representative of the Union for Foreign Affairs and Security Policy, as well as the Member States. Systematically, however, the creation of a sui-generis instrument for CFSP, called a European decision, fits into the system of legislative acts decided under co-decision. Foreign policy with this distinction has also formally been allocated to the executive branch of European government. ${ }^{57}$

\section{The New Typology meets Reality}

The previous two parts of this article reviewed the complex new typology proposed by the Treaty of Lisbon, which re-defines legislative acts and conditions of delegation of executive powers, as well as possibilities for their supervision. This part of the article looks at how the new typology will fit into the context of the problems arising in the daily practice of the creation and implementation of EU law. Structures and procedures for this have developed in an evolutionary fashion over time and with different approaches in different policy areas.

\section{A Distinguishing Delegated Acts from Implementing Acts: Background and Effects}

The central innovation of the new typology of acts proposed by the Treaty of Lisbon is the introduction of a 'third' category of act between acts of legislation and of an implementing nature - the category of delegated acts. The category of delegated acts is a new creation which was originally introduced into the Constitutional Treaty and then

56 This can be illustrated by the effect of the mismanagement of contractual relations that was one of the reasons for the fall of the Santer Commission. See P. Craig, The Constitutionalisation of Community Administration, Jean Monnet Working Paper 3/03, at 20, available at http://www.jeanmonnetprogram. org.

57 See K. Lenaerts and M. Desomer, 'Towards a Hierarchy of Legal Acts in the European Union? Simplification of Legal Instruments and Procedures', (2005) 11 European Law Journal 774, at 754. 
adapted for the Treaty of Lisbon. The idea was to create a category of act which allows unloading of less essential elements of legislative matters to an executive body in order to avoid overly detailed legislation in the EU. ${ }^{58} \mathrm{It}$ is an innovation insofar as the case-law of the ECJ has accepted basically two hierarchical levels in derived law: acts with a legal basis in EC Treaty provisions and implementing acts with a legal basis in a secondary legal act. The former were acts decided under the decision-making procedures provided for in treaty provisions. The latter were implementing acts adopted on the basis of an act of secondary legislation. Implementing acts under the current EC law distinction have covered a wide variety of categories, such as rule interpretation, rule application, rule setting/evaluation, approval of funds, the extension/new specification of funding programmes and information management. ${ }^{59}$ They ranged from single-case decisions to the adoption of acts 'supplementing' or 'amending non-essential elements' of a legislative act. ${ }^{60}$

The attempt to create a third category of acts, however, is not completely new. In the institutional practice, there have been attempts to establish levels 'in between' legislation and implementation. In several policy areas, a third category of delegated powers was developing largely unnoticed by the legal establishment and the interested public. ${ }^{61}$ Originally, in the area of agriculture, but increasingly in various policy areas, a level of delegated acts had been created 'in between' the original legislative act and the implementing acts to be adopted by the Commission. ${ }^{62}$ In many cases, the Council reserved for itself the power to amend or supplement parts of the original legislative acts in a simplified procedure, generally, by excluding the EP from participation rights in the procedure. This approach is generally referred to as an act with a 'derived legal basis ${ }^{93}$

${ }^{58}$ The European Convention, Technical Comments, Draft of Arts 24-33 of the Constitutional Treaty, of 26 February 2003 (CONV 571/03), at 3 and 17; K. Lenaerts, Comment simplifier les instruments d'action de l'Union?, La convention Européen, Working Group IX, Working document 07 (22 Octobre 2002), at 2-4; Stancanelli, op cit n 5 supra, at 511.

${ }^{59}$ See G. F. Schaefer and A. Türk, 'Legislation and Implementation: Theoretical Considerations and Empirical Findings', in The Role of Committees in European Policy-Making and Policy Implementation, Final Report (EIPA, 2002); Hofmann and Türk, op cit $\mathrm{n} 9$ supra, at 74.

${ }^{60}$ See Art 1(2) and (5) of Council Decision of 17 July 2006 amending Decision 1999/468/EC laying down the procedures for the exercise of implementing powers conferred on the Commission, [2006] OJ L200/11, including a new Art 2(b)2 on regulatory procedure with scrutiny into the comitology decision, which provides for EP supervision and limited participation. The 2006 comitology decision (amending the 1999 comitology decision) was formulated in view of the hierarchy of norms provided for in Art I-32 of the Constitutional Treaty, which, expanding the EP rights with respect to both the 1987 and the 1999 comitology decisions, had already contained provisions allowing implementing acts to amend nonessential provisions of a delegating act through the regulatory procedure. See M. Szapiro, 'ComitologyThe Ongoing Reform', in H. C. H. Hofmann and A. Türk (eds), Legal Challenges in EU Administrative Law (Elgar, 2009) forthcoming.

${ }^{61}$ This type of question has been subject to case-law of the ECJ in C-133/06, Parliament $v$ Council (Refugee Status), 6 May 2008, nyr, paras 43-63 and C-93/00, Parliament v Council (Beef Labelling) [2001] ECR I-10119, paras 38-43. The Court stated that the principle of limited attribution of powers under Art 7(1) EC also required that each institution is to act within the limits of the powers conferred on it by the Treaty. It thereby found a measure adopted on a derived or secondary legal basis providing for a different decision-making procedure than that provided in the Treaty to be illegal. Advocate General Poiares Maduro in his Opinion in C-133/06, Refugee Status strictly advised the Court to adhere to this approach, while Advocate General Stix-Hackl in C-93/00, Beef labelling suggested to allow for acts with derived legal basis under certain conditions.

${ }^{62}$ U. Wölker, Die Normenhierarchie im Unionsrecht in der Praxis', [2007] Europarecht 32, at 36.

${ }^{63}$ As far as I can see, Advocate General Stix-Hackl had coined this phrase in her opinion in case C-93/00, op cit $\mathrm{n} 61$ supra, para 41. 
or 'secondary legal basis'. ${ }^{64}$ In nearly all of the cases of derived legal basis, the original legislative act delegates to the Council the power to take further legislative measures or amendments of the original act. Only recently has the ECJ very clearly stated the illegality of derived legal basis, after their use had expanded from agriculture and fisheries to environment, structural and agricultural funds, banking and finance regulation and other areas. ${ }^{65}$ The expansive use of this approach may be largely due to the fact that judicial review of measures which have a legal basis in an act with a derived legal basis has not been undertaken ex officio by the ECJ and has not often been argued by the parties in the case. ${ }^{66}$ Also, in many cases, the derived legal basis had been the result of a political compromise and therefore not attacked by the institutions.

Therefore, when looking at this existing practice, it appears that the category of delegated acts has predecessors. It was developed from institutional practice and expanded to include delegation through derived legal basis for certain non-essential legislative matters. It was also developed from the evolution of the comitology system towards an increasing inclusion of parliamentary participation in quasi-legislative regulatory activity delegated to the Commission under the regulatory procedure and the 'regulatory procedures with scrutiny'. ${ }^{67}$

A comparison between Article 290 FEU on delegated acts and Article 291 FEU on implementing acts also shows that both have very different wording and do not seem to be written in the same style and approach. ${ }^{68}$ Given the parallel existence of these two different categories of act, the question arises whether this differentiation will have an influence on the extent and conditions of delegation and, thereby, on concepts of legitimacy of EU activity. More generally, the question arises as to why one should differentiate between the two categories of sub-legislative act. Why should there be the parallel possibility of delegated legislation in the form of Commission 'delegated regulations, directives and decisions' and Commission 'implementing regulations, directives

${ }^{64}$ See the terminology used in C-133/06, op cit $\mathrm{n} 61$ supra.

65 The examples for this type of approach delegate to the Council decision-making powers with a simplified procedure generally omitting participation rights by the EP and/or the Economic and Social Committee. Examples can be found in many policy areas. In case C-133/06 Refugee Status, the Council thus referred to an existing institutional practice establishing secondary legal basis. The most prominent example it cited might be within the merger control regulation, which in Art 1(5) of Council Regulation (EC) No 139/2004 of 20 January 2004 on the control of concentrations between undertakings-EC Merger Regulation, [2004] OJ L24/1, provides for a simplified amendment procedure without EP involvement. The ECJ followed the opinion of its Advocate General Maduro affirming that institutional practice cannot give the power to derogate from Treaty provisions. Thereby, the ECJ implicitly but importantly overrules the landmark ruling in case C-25/70, Einfuhr- und Vorratsstelle für Getreide und Futtermittel v Köster [1970] ECR 1161, para 6, which relied, inter alia, on consistent practice of the Community institutions to justify the legality of a comitology procedure. Institutional practice as reason for developing practices beyond the Treaty provisions - a notion from public international law-is therewith officially revoked in EC law.

${ }^{66}$ So far as can be seen the argument of the illegality of a derived legal basis has been made only in the two above cited cases C-93/00 and C-133/06. In many other cases, where legal acts based on derived legal basis have been subject to the dispute, the ECJ did not review the legal basis of the act.

${ }^{67}$ See P. Craig, EU Administrative Law (Oxford University Press, 2006), at 127.

68 This observation of course would also have been true with respect to Arts I-32-36 of the Constitutional Treaty from which Arts 288-291 FEU have been largely copied. As Mehdi and Picod rightly conclude, 'la situation finalement consacrée à propos des acts non legislatifs apparaît pour le moins confuse'. See R. Mehdi and F. Picod, 'Article I-33', in Burgorgue-Larsen et al, op cit $\mathrm{n} 8$ supra, para 26. 
and decisions'? After all, this differentiation is prone to produce considerable confusion on the side of non-expert citizens. ${ }^{69}$

Two explanations seem plausible. First, the distinction between the two categories of act can be interpreted in view of the historic development as the result of a compromise between two schools of thought on the horizontal separation of powers between Community institutions, which were represented within the convention leading to the Constitutional Treaty: one opinion held that the Commission as the prime EU executive body should play an eminent role in implementing and forming EU legislation. This approach would argue in favour of far-reaching delegation to the Commission, which would have resulted in stronger 'regulatory' legitimisation of the Union. The other school of thought claimed that a restricted and controlled role of the Commission in implementing EU law can be achieved by implementation under the supervision of comitology or similar procedures to parliamentary supervision. Thus, the strengthening of the EP's position in the area of delegated acts through the new comitology procedure called 'regulatory procedure with scrutiny' was introduced in the 2006 Comitology Decision. Both opinions are represented in the solution of the Lisbon Treaty.

The second explanation reveals at closer inspection another trend. The distinction between the categories of delegated acts and implementing acts reflects also the attempt to re-invigorate the concept of a clearer distinction of powers between the EU and the Member States with respect to implementation, ie the vertical separation of powers. This concept has come to be known as executive federalism. ${ }^{70}$ It represents a rather traditional notion of administration in the EU: the distribution of functions takes place within a two-level system. Under the concept of executive federalism, European interventions in certain policy areas are made through legal acts of legislative nature. The role of the Member States in this picture is to implement these provisions. Implementation at the European level through direct administration is the exception to indirect administration by the Member States. The exceptional case of implementing activity on the European level results form a delegation of administrative powers to Community institutions, either in primary or normally in secondary law or from implied powers. This picture of executive federalism is reinforced in the distinction between Articles 290 and 291 FEU. Article 290 FEU establishing the category of delegated acts allows for certain delegation of legislative competencies to an executive body under Parliament and Council supervision. So far, it remains within the optique of federal rule making. Article $291 \mathrm{FEU}$ on implementing acts explicitly affirms the basic competence of Member States to adopt all implementing acts. ${ }^{71}$ But it also allows that implementing

${ }^{69}$ The new formulation of Art 263 FEU which regulates standing of non-privileged actors against acts of an abstract-general nature shows that with respect to standing in court, no differentiation of the kind proposed by Arts 290 and 291 FEU is necessary. Article 263 FEU refers to all types of 'regulatory acts' (delegated and implementing) as opposed to single-case implementing acts. It thereby implicitly only asks for the nature of an act - abstract-general or not - to establish standing in court.

${ }^{70}$ See for the description of the classic model of executive federalism, eg, K. Lenaerts, 'Some Reflections on the Separation of Powers in the European Community', (1991)28 Common Market Law Review 11, at 11 et seq; B. Dubey, 'Administration indirecte et fédéralisme d'exécution en Europe', (2003) Cahiers de Droit Européen 87. For a view which emphasises the cooperative nature of executive federalism, see, eg, P. Dann, 'European Parliament and Executive Federalism: Approaching a Parliament in a Semi-Parliament Democracy', (2003) 11 European Law Journal 549.

${ }^{71}$ This is also related to the obligations arising from the 'principle of sincere cooperation' of the Member States under Art 4(3) EU (Lisbon) that 'Member States shall adopt all measures of national law necessary 
powers may be conferred by legislation to the Commission or the Council to establish uniform conditions for implementation. For this, legislation will be passed to establish 'rules and general principles concerning mechanisms for control by Member States of the Commission's exercise of implementing powers' ${ }^{72}$ From this perspective, the interesting element of the distinction between Article 290 and 291 FEU is that control of delegated acts is conducted by EU institutions, whereas implementing activity at the European level is under supervision of the Member States (represented in Council).

These considerations show that the problem of the distinction between delegated acts and implementing acts needs to be seen in view of differing conceptions of multilevelism consistent in the EU. A more federal-style model would follow an approach of distinguishing clearly between a two-level structure with the Member States on one level and the EU as quasi-federal structure on the other. The Treaty of Lisbon's strengthening of executive federalism by legal definitions in Articles 290 and 291 FEU, however, runs fundamentally counter to the developments in reality of an ever-more integrating legal system in the EU. Therein, in absence of a distinct European 'federal' bureaucracy, forms of administrative network structures have created an integrated administration. The reality of today's EU system is characterised by intensive cooperation of administrative actors from the Member States and the EU. In this process, the now traditional distinction of direct and indirect administration has become increasingly blurred. ${ }^{73}$ The EU is thus in reality characterised by its multi-level cooperative structures, designed to include the different decision-making levels and generate knowledge in the administrative system prior to taking decisions. ${ }^{74}$ The mix of forms differs according to the context.

In summary, the two different types of delegated and implementing acts with different forms can be interpreted as an attempt to re-establish the traditional notion of executive federalism in the form of positive law. But the necessities of administrating a single market and many joint policies by means of close cooperation between the national and the European executive actors are so fundamental, it might be reasonably doubtful whether they could be defined away with a formulation in Articles 290 and 291 FEU. The reality of the developing integrated administration most likely will follow real regulatory requirements more closely than the fine points of the distinctions between Articles 290 and 291 FEU suggest. What remains however, is - to the

to implement legally binding Union acts'. This Article has replaced the former Art 10 EC, which states, inter alia, that the 'Member States shall take any appropriate measure, general or particular, to ensure fulfillment of the obligations arising out of the Treaties or resulting from the acts of the institutions of the Union'.

72 Emphasis added.

${ }^{73}$ See on the increasing importance of these composite administrative procedures, S. Cassese, 'European Administrative Proceedings', (2004) 68 Law and Contemporary Problems 21; G. della Cananea, 'The European Union's Mixed Administrative Proceedings', (2004) 68 Law and Contemporary Problems 197; M. P. Chiti, 'Forms of European Administrative Action', (2004) 68 Law and Contemporary Problems 37; C. Franchini, 'European Principles Governing National Administrative Proceedings', (2004) 68 Law and Contemporary Problems 183; E. Schmidt-Aßmann, 'Verwaltungskooperation und Verwaltungskooperationsrecht in der Europäischen Gemeinschaft', (1996) Europarecht 270; G. Sydow, 'Die Vereinheitlichung des Mitgliedstaatlichen Vollzugs des Europarechts in Mehrstufigen Verwaltungsverfahren', (2001) Die Verwaltung 517; G. Sydow, Verwaltungskooperation in der Europäischen Union (Mohr, 2004).

${ }^{74}$ See for further analysis of the developments of the past decades, H. C. H. Hofmann and A. Türk, 'The Development of Integrated Administration in the EU and its Consequences', (2007) 13 European Law Journal 253 and H. C. H. Hofmann and A. Türk, 'Conclusions_Europe's Integrated Administration', in Hofmann and Türk, op cit n 9 supra. 
outside - a complex structure of forms of acts, which lacks transparency. The opaqueness of EU law has been deliberately taken to a new level in order to make an abstract theoretical point of typology to press the EU into a state-like federal model.

\section{$B$ The Future of Comitology}

One of the central differences between the two categories of delegated acts and implementing acts under the Treaty of Lisbon will be the mode of supervision of the Commission with respect to the delegated matter. In the case of delegated acts, the EP and Council can reserve the right to either revoke the delegation or to object to a proposed measure. Implementing acts would, on the other hand, be subject to newly defined comitology rules.

Given the influence of the new typology of acts, one of the conditions of comitology, the likely effects of the Treaty of Lisbon's reforms on the development of comitology, is essential. Comitology (with agencies which are addressed in the following sections below) is the fundamental structure of integrated administration to administer EU policies. But supervision of implementing powers delegated to the Commission with the help of comitology procedures has also, to date, been one of the major sources of inter-institutional conflict. The differences of Articles 290 and 291 FEU with respect to political supervision of delegated and implementing acts can thus be interpreted as a between-the-lines commentary on the underlying developments of Europe's increasingly integrating administration. The question of whether there should be two distinct sub-legislative categories of delegated acts and implementing acts therefore inscribes itself firmly into the history of the institutional dispute about the rights of the EP to participate in recourse decisions. In fact, the history of the debate on the introduction of a new typology of acts has been largely influenced by this problem. ${ }^{75}$ For decades, the discussion raged as to whether comitology was either part of the problem of establishing more democratic forms of governing the EU or whether comitology was a unique contribution to democratic governance through creating forums for deliberation of interests. $^{76}$

In this dispute, despite continuous rounds of reform, the EP gained only very limited rights in the comitology procedure. Under the comitology procedure with most participatory rights of the EP, the so-called regulatory procedure with scrutiny, the EP has gained genuine participation rights with the possibility of opposing the entry into force of an implementation measure, under certain circumstances. ${ }^{77}$ The regulatory

\footnotetext{
${ }^{75}$ Bradley, op cit $\mathrm{n} 33$ supra; C. F. Bergström, Comitology-Delegation of Powers in the European Union and the Committee System (Oxford University Press, 2005). The EP in the 1960s-1980s originally wanted to see the Council barred from too many executive functions. It therefore favoured the Commission's independence from the Council's possibility of recourse through comitology procedures. With growing competence in legislative matters, it changed its position to call for a bigger involvement in the supervision function of comitology over the Commission's power of rule making.

${ }^{76} \mathrm{See}$, eg, with further references A. E. Töller and H. C. H. Hofmann, 'Democracy and the Reform of Comitology, in M. Adenas and A. Türk (eds), Delegated Legislation and the Role of Committees in the EC (Kluwer, 2000), 25; M. Everson and C. Joerges, 'Re-conceptualising Europeanisation as a Public Law of Collisions: Comitology, Agencies and an Interactive Public Adjudication', in Hofmann and Türk, op cit n 9 supra, 512.

${ }^{77}$ See Art 5a(3) of Council Decision 1999/468/EC of 28 June 1999 laying down the procedure for the exercise of implementing powers conferred on the Commission (Comitology Decision) as amended by Council Decision 2006/512/EC of 17 July 2006 amending Decision 1999/468/EC, [2006] OJ L200/11.
} 
procedure with scrutiny is applicable in cases where the original delegating act was adopted under the co-decision procedure. It is designed to allow for far-reaching delegation of measures of 'general scope designed to amend non-essential elements' of the delegating instrument. ${ }^{78}$ It was introduced in the comitology decision in 2006 in view of the impasse of the ratification procedure of the Constitutional Treaty in order to implement certain elements of the latter's Article I-36.

However, the fact that for implementing acts, Article 291(3) FEU, unlike Article 202 EC, third indent, explicitly refers to comitology only as a 'mechanism for control by Member States', does not exclude the EP from having certain supervisory powers. These supervisory powers can be provided for in the new comitology decision necessary for matters of implementing acts. The EP can influence this new comitology decision since the EP has received a strengthened role in comitology insofar as, under Article 291(3) FEU, the comitology decision would be taken by regular legislative procedure, ie by co-decision. ${ }^{79}$ That will allow the EP to influence the future structure of comitology procedures to a much larger extent than has been possible so far.

So the question arises whether the introduction of the distinction between delegated and implementing acts has not actually made parts of the comitology proceduresespecially those addressing far-reaching delegation, such as allowing for amendments of non-essential elements of the law-obsolete. Despite this being true due to part of the definition of the measures being contained in treaty provisions, the details of the supervision provisions for delegated acts will need to be established in some form of document, possibly an inter-institutional agreement. Alternatively, both procedures for delegated and implementing acts can be regulated in a newly adapted comitology decision. The latter would be the most pragmatic solution, which could consist of splitting the existing comitology decision and redistributing the procedures contained therein to the two different types of act - the delegated acts and the implementing acts. Declaration No 39 in the final act of the Treaty of Lisbon on Article 290 FEU stating that the Commission has the 'intention to continue to consult experts appointed by the Member States in the preparation of draft delegated acts in the financial services area' might be interpreted in this sense. ${ }^{80}$ It looks as if both the EP and the Commission would stand to gain from a solution in which a framework for delegation and the control of delegated powers were fixed in a fashion similar to the current comitology procedures. It would help to develop both the regulatory legitimacy to govern by expertise and the parliamentary legitimacy to guarantee parliamentary oversight into the exercise of executive powers.

78 There under, the Commission shall present draft measures to the EP which by majority and the Council which by qualified majority voting, respectively, may oppose the adoption of the said draft by the EP. Reasons for such opposition may be the ultra-vires nature of the measure or that the EP holds that the draft measure presented by the Commission is not compatible with the aim or the content of the delegating legislation. See Arts 5(a)(3)(b) and 5(a)(4)(e) of Council Decision 1999/468/EC, n 77 supra.

79 This is unlike Art 202 EC, under which the comitology decision was taken by a unique quasi-legislative procedure by the Council acting unanimously upon a proposal from the Commission and after obtaining the opinion of the EP.

${ }^{80}$ The explicit mentioning of financial services in the declaration might, on the other hand, also be interpreted as a commitment to the continuation of the Lamfalussy procedures, especially the level three procedures in which experts of the regulated service industries can contribute. See Lenaerts and Desomer, op cit n 57 supra, at 755 . 


\section{Agencies}

Under the current EC and EU treaties, there is a continuously growing gap between the prolific creation of agencies in the EU and conferral of powers on them, on the one hand, and their recognition in EU primary treaty law, on the other hand ${ }^{81}$ It is a fact that EU legislation transfers functions directly to agencies without the intermediary of the European Commission intervening. ${ }^{82}$ The gap between silence in primary law and recognition in secondary law will remain under the Treaty of Lisbon. The detailed mentioning of agencies was perhaps regarded too mundane to be addressed in a constitutional document such as the Constitutional Treaty. This trend is continued under the Treaty of Lisbon. ${ }^{83}$ As a consequence, agencies, despite being mentioned as potential sources of reviewable final acts in Article 263(1) FEU, final sentence, are not mentioned as recipients of delegation of powers to issue implementing acts. This is explicitly reserved to the Commission or, exceptionally, to the Council. The limitation to the delegation of implementing powers exclusively to the Commission constitutionalises a strict understanding of what is known as the 'Meroni doctrine'-a limitation to delegation established in the early days of European integration within the framework of the ECSC Treaty. ${ }^{84}$ In Meroni, the ECJ had considered as unlawful the delegation of discretionary powers to a private body containing the authorisation to take discretionary decisions and which went beyond the delegation to clearly defined powers. ${ }^{85}$ The practical reality of executive structures and the legal situation under EU law is now, however, far more complex than in the 1950s when Meroni was decided under very

${ }^{81}$ D. Curtin, 'Delegation to Non-Majoritarian Agencies and Emerging Practices of Public Accountability', in Geradin et al, op cit, n 2 supra; D. Fischer-Appelt, Agenturen der Europäischen Gemeinschaft (Duncker und Humblot, 1999), 87.

${ }^{82}$ Examples of agencies which have received legislative delegation for single case and restricted regulatory decision-making powers are the Office for the Harmonisation of the Internal Market (OHIM), which is empowered to take legally binding decisions on the registration of Community trade marks and other intellectual property rights (see Art 43(5) and 45(6) of Council Regulation 40/94 of 20 December 1993 ([1994] OJ L11/1) on the Community trademark (as amended in [1994] OJ L349/1 amd [1995] OJ L303/1). The Community Plant Variety Office (CPVO) has been delegated the power to adopt legally binding decisions in relation on the registration of plant variety rights (Art 62 of Council Regulation 2100/94 of 22 July 1994 on Community plant varieties, [1994] OJ L227/1 amended in [1995] OJ L258/1). Powers akin to regulatory powers have been granted to the European Air Safety Agency (EASA) to adopt decisions with regard to criteria for type certification and continued airworthiness of products, parts and appliances, and the environmental approval of products (Regulation (EC) 1592/2002 of the European Parliament and of the Council of 15 July 2002 on common rules in the field of civil aviation and establishing a European Aviation Safety Agency, [2002] OJ L240/1).

${ }^{83}$ However, number 6 of the horizontal amendments to the EC Treaty in the Treaty of Lisbon provides for the replacement of the word 'institution' or 'institutions' in the EC Treaty to be replaced in all Articles of the FEU by 'institution, body, office or agency' or 'institutions, bodies, offices or agencies'. But these developments touch provisions on control of agency action not provisions on the extent of powers to be delegated.

${ }^{84}$ Cases 9 and 10/56, Meroni v High Authority [1957/58] ECR 133. For a precise outline of the Meroni doctrine, see R. Dehousse, 'The Transformation of EU Governance', in Joerges and Dehousse, op cit n 4 supra, 220.

${ }^{85}$ Such limitation of recipients of delegation might be intended to safeguard the coordinating role of the Commission for executive measures on the EU level. It, however, disregards the existing gap between the institutional reality in EU law and the constitutional situation. See for a discussion of these agency-related problems, E. Chiti, 'Decentralisation and Integration in the Communty Administration: A New Perspective on European Agencies, (2004) 10 European Law Journal 402; Craig, op cit n 67 supra, at 160-164 and 184; M. Everson, 'Independent Agencies: Hierarchy Beaters?', (1995) 2 European Law Journal 180; M. Koch, Die Externalisierungspolitik der Kommission (Nomos, 2004). 
specific circumstances under the law of the ECSC Treaty. An increasing number of agencies undertake administrative functions and have been created effectively to carry out complex tasks in the network of administrative structures between the European level and the level of the Member States. Especially, regulatory agencies prepare or issue externally binding decisions. Most types of agencies are involved in contractual relationships with private bodies and administrations of Member States. The EU's constitutional reality, backed by the case-law of the ECJ, has therefore been developed to a degree which has quite broadly overcome the Meroni doctrine. With the exclusion of delegation of powers to agencies, under the Treaty of Lisbon (as well as already provided for in the Constitutional Treaty) the Meroni doctrine has been re-iterated in primary law. The divide between the constitutional provisions and the requirements of the architecture of the emerging European network administration, which includes European agencies, will increase.

\section{Sub-Delegation}

The possibility of sub-delegation is an additional result of the distinction between the two categories of delegated and implementing acts in Articles 290 and 291 FEU. This possibility will arise especially in areas of broad delegation of legislative powers to the Commission under Article 290 FEU. The Commission may then be obliged (under Article $291 \mathrm{FEU}$ ) to sub-delegate to itself implementing powers. ${ }^{86}$ This combination of provisions may thus result in a cascade of delegation of powers. It also risks subverting the possibilities of political supervision of the exercise of these delegated powers. Such cascades of delegation could become problematic if, by means of sub-delegation, the Commission could escape well-established review procedures such as the comitology procedures. Under the current comitology decision, this would be possible, since the application of one of the comitology procedures for the delegation of implementation powers is a decision within the discretion of the legislator ${ }^{87}$ When undertaking whether to choose one of the committee procedures under the criteria which are laid down in Article 2 of the comitology decision, the legislator must merely 'state the reasons for that choice. ${ }^{8}$ Under the current comitology decision, it is therefore possible, and likely, that in the subject area of delegated acts the Commission will decide that it will itself have the power to issue implementing acts in the form of implementing regulations or implementing decisions without being bound by a comitology procedure. This would fit into the explicitly stated critical approach of the Commission towards comitology. It has regarded comitology, in the recent past, very negatively and has suggested that comitology structures be replaced with agency networks. ${ }^{89}$

\footnotetext{
${ }^{86}$ Whereas the power to issue delegated acts requires a legislative delegation, the power to issue implementing acts can explicitly be delegated by any 'legally binding Union act', including a delegated regulation, directive or decision under Art 290 FEU.

${ }^{87}$ Case-law since Case 30/70, Scheer [1970] ECR 1197, para 18.

${ }^{88}$ Case C-378/00, Commission v Parliament (LIFE) [2003] ECR I-937, paras 51-55.

${ }^{89}$ See the European Commission, European Governance: A White Paper, COM (2001) 428 (25 July 2001), in which it suggested to restrict the role of Committees to mere advisory function. For further discussion, see Craig, op cit n 67 supra, at 112, 113 and 126, 127; M. Everson, 'Agencies: The "Dark Hour" of the Executive?', in Hofmann and Türk, op cit n 60 supra. The very negative stance of the Commission towards comitology has, however, in the past few years been softened in public. Even in policy areas in which the Commission has proposed legislation to create new agencies, comitology procedures continue to play an important role. Internally, however, critical positions are strongly voiced. See, eg, D. Tryantafyllou, 'Article I-36 Les règlements européens délégués', in Burgorgue-Larsen et al, op cit n 8 supra, para 18.
} 
From a parliamentary point of view and if the political supervision of executive powers is regarded as something positive, new powers can be counter-balanced only by a strict application with sunset clauses of time limits for delegation to the Commission and strict limitation of delegation of powers to adopt delegated acts. Overall, using comitology in order to maintain political supervision over executive exercise of public powers will only be possible if the EP manages to contain and control delegation cascades with sub-delegation by the Commission from delegated to implementing acts.

A specific legal problem will arise when the Commission has sub-delegated to itself in a delegated act, implementing powers and the original delegation consequently gets revoked by the EP or the Council. The question then arises whether the revocation has effect ex nunc or ex tunc. Generally, revocation should take effect as of the moment it is declared - therefore ex nunc without retroactive effect. This will leave all acts which were decided upon during delegation in force. In view of the possibility of subdelegation by the Commission, this would lead to continuous implementation powers, which the Commission may then exercise outside of political oversight. Essentially, this endangers possibilities of political supervision of the Union's executive branch. Such danger can be encountered if the legislator, when delegating powers to issue delegated acts to the Commission, obtains the combination of both conditions (full-scale revocation or single case affirmation) under Article 290(2)(a) FEU, as well as the possibility to limit the duration of delegation. Such conditions of delegation will explicitly also need to be applicable for revoking sub-delegation powers. Additionally, the EP and the Council will want to take into account these possibilities when developing the new comitology decision under Article 291(3) FEU as a legislative act. Therein, subdelegation could be explicitly addressed and submitted to comitology procedures for the supervision of Commission implementing activities. Such an approach, especially if the EP, next to the Member States, maintains a certain possibility of control, would strengthen the aspect of parliamentary legitimation of executive activity.

\section{Review and Conclusions}

Looking at the introduction of the new typology of acts introduced by the Treaty of Lisbon in review, it appears that it has the potential to change considerably the conditions of delegation through the introduction of a highly complex typology of Union acts. On the positive side, the very fact that a hierarchy of norms between formal legislation decided in a legislative procedure by the EP and the Council, on the one hand, and executive rule-making powers based on an explicit legislative empowerment, on the other, has been introduced, is an essentially sensible idea. The positive innovation of the Constitutional Treaty has been maintained. Positive law has therefore finally caught up with institutional reality and the established case-law of the ECJ. Strengthening the use of the hierarchic structures in the EU's legal system by distinguishing between legislative and non-legislative acts is a simple organisational structure which has the potential for strengthening the rule of law within the legal system by increasing the transparency and the requirements for legality of legal acts of the Union. This aspect of the Treaty of Lisbon's new typology of acts is a welcome step in reducing the lack of transparency of the EU's legal system and adding to its overall maturity. ${ }^{90}$

\footnotetext{
${ }^{90}$ For a further analysis of the historic development, see Lenaerts and Desomer, op cit $\mathrm{n} 57$ supra.
} 
Having said this, it needs to be noted that the relation between delegated acts and implementing acts promises to be fraught with difficulties. The articles relating to the two different categories of acts are formulated in very different manners and do not relate to each other. The new distinction between delegated and implementing acts in the FEU contains considerable difficulties and holds serious risks. The parallel existence of these two categories of act will lead to inter-institutional dispute about the limitations of delegation and sub-delegation. The distinction distracts from the real problems of including EU agencies and legal forms and conditions of EU network administration.

With respect to the new category of delegated acts, it has to be noted that they can be held subject to much more direct parliamentary supervision than the existing comitology committee procedures allowed for. So far, the EP was restricted in the reasons for which it could request revocation under the comitology regulatory procedure with scrutiny. Under Article $290 \mathrm{FEU}$, it will be free to exercise political discretion as to when it may revoke a delegation. This is a large step towards expanding parliamentary political control over delegated powers. The details of such supervision procedures will need to be established in greater detail in specific rules, for example an interinstitutional agreement, in future. Implementing acts will continue to be subject to political supervision, especially by Member States in comitology committees. The extent and conditions of facultative delegation to delegated acts and binding delegation to implementing acts will need to be carefully considered by the legislating institutions. The Treaty of Lisbon allows for a variety of approaches.

With respect to the institutional balance, the winner of the restructuring of the typology of acts in the Treaty of Lisbon might be the Commission if extensive use of delegated powers in delegated acts is undertaken. The Commission maintains its highly influential role in legislative procedures, with the near exclusive right to initiative, whilst expanding its role in legislative measures through the creation of the category of delegated acts. Possible approaches to maintaining the capacity for political control of executive action may include establishing procedures for limitations of sub-delegation, as well as, if allowing the latter, provisions for controlling sub-delegated powers in the case of revocation of the original legal basis. The future of the comitology regime will be an important element of putting the Treaty of Lisbon's provisions into action, even if only marginally mentioned with respect to implementing acts in Article 291 FEU. A pragmatic adaptation of the comitology provisions will be a central element of the working of the new typology in reality.

The transfer from the Constitutional Treaty to the Treaty of Lisbon has left several inconsistencies with respect to the constitutional versus treaty nature of the Treaty of Lisbon. In the constitutional vein, the Treaty of Lisbon does not recognise the reality of the implementation of European law through administrative networks made up of European and Member State public bodies, as well as private parties. The Treaty of Lisbon ignores the development of using agencies for implementation. In this respect, the typology of acts is not conclusive, even though the list in Article 253(3) FEU would allude to indicate comprehensiveness. ${ }^{91}$ Most importantly, however, the Treaty of Lisbon has created an unintelligible categorisation creating nine basic forms of acts. It does so by maintaining the forms of regulations, directives and decisions for all three levels of legislative, delegated and implementing acts. The true nature of a European act

\footnotetext{
91 Also, the Treaty of Lisbon lists only unilateral forms of action such as implementing regulations and decisions. Contracts and soft law tools find no mention in the Articles on implementing acts.
} 
will remain a mystery to all but the limited circle of cognoscenti of European law. Therewith, transparency with respect to the meaning and the responsible institutions for an act has been sacrificed. The result is a sad example of unnecessary complexity and un-intelligibility of European treaty provisions. Additional items which lack transparency will arise from the open question of the transfer regime from the old set of rules under the EC and EU treaties to the new Lisbon typology of acts. ${ }^{92}$

All in all therefore, the picture of the reforms of the Treaty of Lisbon is mixed. On one hand, strengthening the system by introducing certain elements of a hierarchy of norms by distinguishing between legislative and non-legislative acts is a positive contribution to enforcing political supervision over executive actors. The way in which this reform has been introduced and the outcome is, on the other hand, complex and burdensome, and will probably further reduce transparency and intelligibility of the legal system of the EU. Many future institutional conflicts especially over the distinction between delegated and implementing acts are foreseeable. Much remains to be done for future Treaty reforms.

First Submitted: May 2008

Final Revision Accepted: December 2008

92 The Treaty of Lisbon does not contain explicit guidelines for the transformation from the old to the new regime. Legal acts issued under the EU and EC treaties would therefore remain in force until amended or abolished. This approach at first sight seems wise in view of the difficulties with the attempt to transform the committees established before and after the first comitology decision was adopted in 1987 to the new system of comitology under the second comitology decision of 1999 (Council Decision of 28 June 1999 ([1999] OJ L184/23). In practice, however, the non-transformation will cause intransparency since, for a long period of time, the old and the new terminology will be used in parallel. 